\title{
DIPLOMATIC IMMUNITY AND ENCRYPTED DIPLOMATIC CORRESPONDENCE IN THE OTTOMAN EMPIRE
}

\author{
Sedat BINGÖL* - Hayrettin PINAR**
}

\begin{abstract}
The Ottoman Empire, which was in continuous communication with the surrounding world since its first establishment, built up a rich body of diplomatic correspondence over the course of its history. Among the most important headings of its documented communications related to diplomat immunity and encrypted correspondence. In spite of their diplomatic immunity, Ottoman diplomats acted largely within the framework of the customary law observed in the countries in which they operated. Thus, both the behavior of the Ottoman diplomatic representatives and their communiques were shaped less by statutory law than through the experience provided by international law. In this article We will base on another aspect of the capitulations, in which Ottoman historians are only interested in the economic aspect. Within the framework of the capitulations, the attitude changes of the Ottoman State on diplomatic immunities was traces determined.
\end{abstract}

Keywords: Ottoman Empire, Diplomacy, Customary Law, Encrypted Communications, Immunity.

$\ddot{O} z$

Osmanlı İmparatorluğu'nda Diplomatik Dokunulmazlık ve Şifreli Diplomatik Haberleşme

Kurulduğu andan itibaren etrafındaki dünya ile temasa geçen Osmanlı, tarihi süreç içinde zengin bir diplomasi birikimi elde etmiştir. Diplomasinin en önemli başlıkları arasında yer alan evrak ve haberleşme dokunulmazlığı da zamanla Osmanlı hariciyesinin birikim kazandığı alanlardan biri olmuştur. Osmanlılar diplomatik dokunulmazlıklar konusunda ilişkiye girdikleri ülkelerle daha çok teamül hukuku çerçevesinde hareket etmişlerdir. Dolayısıyla hem diplomatik temsilcilerin, hem de onların yazışmaları ve haberleşmelerine ait dokunulmazlıkların, yazılı olmaktan daha çok devletlerarası hukukun sağladığı birikimle şekillenmiştir. $\mathrm{Bu}$ makalede Osmanlı tarihçilerinin genellikle iktisadi boyutuyla ilgilendikleri, Ahidnamelerin başka bir yönünü esas alacağız. Ahidnameler çerçevesinde Osmanlı Devleti'nin diplomatik dokunulmazlıklar konusundaki tutum değişikliklerinin izleri tespit edildi.

\footnotetext{
* Assoc. Prof., Anadolu University, Faculty of Humanities, Department of History, Eskişehir/ Turkey. E-mail: sbingol@anadolu.edu.tr. ORCID: 0000-0003-2016-2819

** Assoc. Prof., Eskişehir Osmangazi University, Faculty of Science and Letters, Department of History, Eskişehir/ Turkey. E-mail: hpinar@ogu.edu.tr. ORCID: 0000-0002-7261-2394

(Makale Gönderim Tarihi: 02.01.2021 - Makale Kabul Tarihi: 20.05.2021)
} 
Anahtar Kelimeler: Osmanlı İmparatorluğu, Diplomasi, Teamül Hukuku, Şifreli Haberleşme, Dokunulmazlık.

\section{Introduction}

Learning that the Venetian Bailo Girolamo Marcello had sent encrypted communiques home to his government, Sultan Bayezid II (r. 1481-1512) expelled him from Ottoman territory in 1492. With that act, the most distant Venetian colony of Cyprus was deprived of a representative in Istanbul for years to come. ${ }^{1}$ The event is important for our understanding of how secret communications was understood by the Ottoman Sultanate and its bureaucratic apparatus. Not one century later, secret correspondence had become a familiar and important part of Ottoman diplomacy. In fact, 1566, it was seen that the interpreter Colombina, who had converted to Islam, was given the task of teaching Ottoman officials the art of deciphering Venetian encrypted correspondence. ${ }^{2}$

These two cases present an exemplary model for the changes in how the Ottomans viewed foreign affairs. What was once regarded as dangerous came to be seen as an important element of diplomacy by the middle of the following century. The employment given to Colombina shows that encryption in correspondence was no longer was considered to be suspicious in itself. Following Istanbul's conquest-oriented approach to international relations, this event revealed that a relational/reconciliation perspective had appeared in 1566 .

The fact that the use of encoding and decoding was developed by the Ottoman administration over a relatively short period became evident in an event of the mid-17th century, during the grand viziership of Köprülü Mehmed Pasha, which indicated that encrypted correspondence was no longer considered bizarre in the conduct of foreign affairs in the Ottoman Empire.

While the Ottoman army was in the process of conquering Heraklion during the Cretan Campaign, the covert aid that France had been providing to Venice was observed. France's ambassador in Constantinople, Jean de la Haye, was holding secret meetings with Venetian representatives. A French officer named Vertamont serving in the Venetian Army made contact with the Ottoman authorities in 1659 and revealed the secret. This situation developed further when Vertamont stated his desire to settle in Istanbul for personal reasons and even convert to Islam, saying that he was willing to offer many letters that the grand vizier would want to see.

Word of Vertamont's leak of this correspondence caused upheaval at the French Embassy. De la Haye took the drastic step of sending his panicked cryptography officer into hiding to prevent his possible abduction. ${ }^{3}$ De la Haye was summoned to Edirne for an explanation, but he dispatched his son and a staff member instead, citing illness. The

${ }^{1}$ Potyemkin vol. 1 2009, p. 155; Pilat and Criesta, 2018, p. 260; Frazee 2004, p.227

2 E. S. Gürkan 2014, p. 288; Gürkan 2017, pp. 147, 250.

${ }^{3}$ In a previous incident, an embassy secretary expressed his horror when he recalled how a Venetian interpreter had been tortured when he would not give up his password key. "Sir, I have an fearful character and I want to inform your worthy self that there is no secret I wouldn't divulge the moment the beating starts, so I suggest you either hide me or else smuggle me away from here." Chardin 2014, p. 44. 


\section{Diplomatic Immunity and Encrypted Diplomatic Correspondence in the Ottoman Empire}

grand vizier threatened them with torture if the letters were not deciphered, but when they showed that they could not interpret them, they were freed.

At the same time as the Vertamont case, another event occurred that was successfully covered up by de la Haye. Just before Vertamont's visit to Istanbul, another Frenchman, named Quiclet, travelled to the capital with his wife. Quiclet was an officer who worked as a decoder in the service of ambassadors and statesmen. His wife arranged a meeting with de la Haye. Sensing that her husband, who was an impoverished man, could benefit selling secrets to the grand vizier, she attempted to blackmail the de la Haye into providing benefit himself. Realizing the danger that this posed, the ambassador invited Quiclet to his mansion, where he had him thrown off of the terrace to his death.

After eliminating this hazard, the French ambassador travelled to Edirne. Showing him the confiscated letters, the grand vizier demanded an explanation. De la Haye responded by saying, "Everyone knows that communiques between the Christian prince and ambassadors and deputies have always been encrypted, regardless of the subject." However, he also informed the vizier that he had sent his encryption clerk back to France six months earlier. This reply was likely considered satisfactory, and de la Haye encountered no ill effects. ${ }^{4}$

It is important that the grand vizier did not pursue confrontation, in that Grand Vizier Köprülü Mehmed Pasha's reaction was quite different and showed greater development than that of Sultan Bayezid II in 1492. An interesting difference is that Bayezid II was concerned about the purpose for which the text was encrypted, but the grand vizier was more concerned with decipherment. Moreover, the grand vizier exhibited no surprise at de la Haye's response. The idea of imbedding a secret language into diplomatic documents no longer came as a shock to those working in foreign affairs in the Ottoman Empire. His request to have the letters deciphered seems to have been more of a statesmanlike reflex than evidence of inexperience in dealing with encryption. ${ }^{5}$

These accounts also indicate the limitations and details of this study. These examples, which occurred between the late 15 th and mid- 17 th centuries, indicate that the Ottoman bureaucracy was sensitive to confidential correspondence. However, this reflex had further softened by the late 17th century. The dynamics that led to this change must be taken into account. The main theme of the Ottoman bureaucracy in the anecdotes reported above was plain-text versus encoded diplomatic document and communications.

\footnotetext{
${ }^{4}$ Chardin 2014, p. 45; Uzunçarş11 vol. III-II 1988, pp. 208-209.

${ }^{5}$ In 1591, Austria sent a tributary legation to Istanbul under the chairmanship of Herr von Kregwitz. When the chamberlain, Ladislaw Mörthen, was punished by von Kregiwtz, he took refuge with Sinan Pasha and converted to Islam, taking the name Ali Bey. He then obtained a permit to search the Austrian legation building with a few sergeants. In the search, the secret documents were seized, and the diplomatic delegation was arrested, along with the envoy, and imprisoned. While this appears to contradict any softening in Ottoman diplomatic style, it should be kept in mind that it occurred just before the Ottoman-Austrian War, which began in 1593 and continued for 14 years. Although Ottoman diplomatic practice gradually approached the dominant European style, the differences between practices during peace and war continued for a long time. Wratislaw 1996, pp. 91-97; Gürkan 2017, p. 146; Teply 1969, p. 249.
} 


\section{Sedat BINGÖL - Hayrettin PINAR}

Diplomatic documents and communications under the heading of immunity marked a limit to the Ottoman diplomatic repertoire during the period and its place in international law.

\section{Development of Diplomatic Immunity in the Ottoman Empire}

In treaties that became the source of international law, states committed themselves to each other or the international community and were required to hold the agreements above all else, in accordance with pacta sunt servanda (loyalty to the treaty). ${ }^{6}$ Loyalty to treaties and international law became a fundamental guiding principle in Ottoman diplomacy during the 19th century. ${ }^{7}$ In particular, the Ottomans resorted to international law and treaty to mitigate the danger posed by Russia. However, treaties were also meticulously followed by the Ottomans even during more salubrious periods of the empire. It is noteworthy that many terms that described the form and content of international relations were incorporated into Ottoman law. These include the terms muâhede, musalaha, and ahidnâme. ${ }^{8}$ The term capitulation is frequently used in the literature in place of ahidnâme.

Throughout the Middle Ages, the Venetians and Genoese of obtained capitulations from the Byzantines, the Anatolian Seljuk State, and the successor principalities as a sign of economic privilege. This continued under the Ottomans. The relations of capitulation, which were shaped by trade at first, expanded over time to include the judicial, religious, and political spheres. Şerafettin Turan's capitulation confirms this, as it is described as, covering

"Commercial, religious, judicial, etc. conveniences and rights bearing privileged elements recognized by a state to the citizens of other states on its territory...containing a one-sided or bilateral treaty or one-sided acceptance certificate." 9

Under this general definition, the specific limitations of the powers granted to the consuls in the Middle Ages varied, according to the country where they were located. The striking point is that cases against consuls could not be judged by local governors. The modern consular institution was founded in the spirit and with the notions of the Middle Ages. ${ }^{10}$

In addition to consuls, the Ottoman Empire began to accept resident envoys of other states. The treaties they concluded included regulations regarding the envoys' residence in Istanbul. Like other European states, the Ottomans initially did not consider it to be suitable to allow representatives of foreign powers to reside in its capital. It is

\footnotetext{
${ }^{6}$ For more information on the opening of permanent representations and immunities adopted by European states in the 15th century, see Mattingly 1955,; Karakoç 2004, p. 199.

${ }^{7}$ Deringil, 1990, pp. 59-70.

${ }^{8}$ Karakoç 2004, p. 239.

9 Turan 1990, pp. 13-14. For more information on the capitulations, see Türkmen 1995, p. 326. ; Pamir 2002, p. 80. Although peace treaties and commercial privileges were declared in imperial decrees until the 19th century, they eventually lost their character as unilateral concessions and became bilateral conventions. Kütükoğlu 1988, p. 540.

${ }^{10}$ Gökbilgin 1952, pp. 838.
} 


\section{Diplomatic Immunity and Encrypted Diplomatic Correspondence in the Ottoman Empire}

clear that envoys did not have the complete trust of the countries where they were assigned.

In 1604, Baron J. De Szilassy said, "An envoy is an honorable man who is dispatched to foreign hands in order to tell lies for his country." 11 The similarity between these observations shows that the distrust of host countries was not necessarily unreasonable. As a matter of fact, envoys were called by some honorable spies, as their work was regarded to incorporate secret diplomacy. ${ }^{12}$ Nevertheless, the Ottoman Empire tended to found its international relations on political and economic grounds. However, although it did eventually subside, mistrust of these honorable spies continued for a long period.

Throughout history, European states added representation through consuls who were not strictly part of the diplomatic mission within the capitulation limitations by calling them deputy envoys. These consuls thus acquired privileges such as being protection from incarceration, expulsion, or replacement by the relevant envoy. The representatives initially treated as consuls in Istanbul were eventually accepted as envoys of their own states and were accredited by the Sublime Porte. ${ }^{13}$

It should be noted that the consuls of European states and their diplomatic missions were granted immunity and privilege. The terms bailo, ${ }^{14}$ envoy, ${ }^{15}$ and consul, which appeared in the imperial decrees, attract special attention. It is well known that consular, as well as diplomatic, relations are established between states. Like diplomats, consuls are officials appointed by one state to work in another. The main difference between envoys and consuls is that, as head of the diplomatic mission, envoys have the power to negotiate high-level political and diplomatic issues, but consuls do not have any rights in these matters. Consuls have the authority to protect the commercial interests and rights of their citizens before the local authorities in the country in which they are appointed. Thus, they are not diplomatic representatives. However, their duties also have an overlapping status that may be defined as a limited form of internationality. ${ }^{16}$

There has been an important change in the authority, duties, and limitations of the consulate relative to its medieval status. This is because throughout the Middle Ages, consuls were responsible for the protection of their citizens and for the commercial and economic interests of the state in which they were citizens.

${ }^{11}$ Bilsel 1934, p. 55.

${ }^{12}$ Mattingly 1955, p. 276; Karl Teply assessed the way in which the Ottomans viewed envoys in the following words:

"The Ottomans would also view all ambassadors as spies and schemers who were officially civil servants... their freedom of movement was strictly restricted. A Janissary unit would was assigned to conduct the restriction task. The same military unit would also serve as the envoy's security detail..." Teply 1969, p. 258.

13 İnalc1k 2000, p. 246.

${ }^{14}$ The bailo was both the consulate of Venetian merchants and the official envoy of the Venetian State in Constantinople. Potyemkin vol 1 2009, p. 148.

${ }^{15}$ The early envoys of the princedoms of the Ottoman Empire, foreign states, were also called baili or kapı kethüdası. Bozkurt 2002, p. 245.

${ }^{16}$ Aybay 2009, pp. 3, 5-9 


\section{Sedat BINGÖL - Hayrettin PINAR}

Moreover, unlike their counterparts of today, they were political representatives. The first state to have the right to have a settled political representative in the Ottoman capital within this vast circle of rights and powers was granted to the Republic of Venice in 1454. France and Britain then opened permanent representation offices in Istanbul and appointed consular officials in 1535 and 1579, respectively. The appointment, legal status, and duties of their consuls were set out in treaties, international conventions, concords, trade agreements, and peace treaties. ${ }^{17}$

Although it continued to have its medieval character until the beginning of the Modern Age, the ambassadorial institution exhibited interesting changes in the 16th and 17 th centuries that were carried forward. After the appearance of the ambassador as a new representative personality, consuls were reduced to commercial attachés who were to follow the commercial and economic interests of their state. Then, with the Treaty of Westphalia of 1648, their political powers were further restricted and transferred to envoys. However, previous practices and arrangements continued in the Ottoman Empire, where consuls maintained their judicial and political authority. ${ }^{18}$

If consuls are to be appointed, there needs to be a common will between the two states. The person chosen to be appointed was reported through diplomatic channels. To examine all of the numerous imperial decrees issued throughout the long history of the Ottoman Empire for statements of diplomatic immunity would exceed the limits of this article. Instead, we deal here with the terms of diplomatic immunity as these manifested themselves through the early 18th century in treaties made with Venice, France, Britain, and finally Austria.

\section{Venetian Imperial Decrees}

Diplomatic relations between the Ottomans and Venice were conducted through the intermediation of baili, Venetian representatives who had been accepted in Istanbul since 1454 as part of a peace treaty, which stipulated that the Republic of Venice could send a bailo and his family to Istanbul in whatever manner it wished. Here, the bailo's family referred to his secretary, his translator (known as the dragoman), his doctor, and other officials, ${ }^{19}$ constituting a diplomatic delegation. An implicit adherence to customary law is evident here. The Ottomans referred to baili as envoys until 1670 and as ambassadors after that. In an edict promulgated in 1575, baili were granted the titles of official representatives of Venice residing in Istanbul. ${ }^{20}$

The Venetians were granted a number of privileges, first by the Byzantine Empire and later by the Aydın and Menteşe Principalities. Most of these privileges were confirmed by the Ottomans during the reign of Sultan Bayezid I (1389- 1402). Following

\footnotetext{
${ }^{17}$ Apaydin 2013, pp. 139-141.

${ }^{18}$ Bilsel 1934, pp. 308-310. Although Ottoman administrators tried to roll back the consuls' powers over time, this was only finally achieved through the Lausanne Treaty (1923).

19 Apaydin 2013, pp. 141, 156. ; Carlo Coco states that the family in question were clerks, a financier, a physician, a notary, and servants in the service of the bailo office. Coco 1991, pp. 670 .

${ }^{20}$ Mumcu, 2014, p. 16.
} 


\section{Diplomatic Immunity and Encrypted Diplomatic Correspondence in the Ottoman Empire}

Bayezid I, Ottoman-Venetian relations continued under Süleyman Çelebi, Musa Çelebi, Çelebi Mehmed, and Murad II. After the conquest of Istanbul, a new commercial agreement was signed with the Republic of Venice in $1454 .^{21}$ A permanent bailo (Venetian envoy) was posted to Istanbul under the Treaty of Constantinople (1479). This treaty was renewed by Bayezid II in 1482. An accompanying imperial decree stipulated, "Let them send their baili to Istanbul... Let them reside in Istanbul and oversee the business of their merchants and apply their own laws. "22 An imperial decree of October 1503 limited the bailo's term to just one year. ${ }^{23}$ However, this term was then extended to three years in an edict issued by Bayezid II. No mention of diplomatic immunity appeared in these decrees.

A clause concerning immunity was added to the imperial decree of 1513 . This stipulated that a bailo could not be taken into custody for someone else's debt, and he could not be held liable for that debt. These clauses appeared in 1517 imperial decree of Sultan Selim I (1512-1520). ${ }^{24}$

The bailo's term of residence was again given as three years in a decree of 1521 , issued within the first year of Süleyman I reign (1520-1566). An interesting detail on immunity was added: "If a person has a dispute with a bailo... If he is in Istanbul, he should negotiate with the government... Baili should not be held in custody and made to pay someone else's debt." 25 These statements were preserved in the 1540 and 1567 imperial decrees to renew the bailo position. Sultan Selim II (1566-1574) continued the pattern of confirming his forerunners' assertions of rights with his decree of 1573 . The same is true for the decree of 1575 on the occasion of the coronation of Murad III (1574 1595). In fact, the same stipulations were preserved in the decrees of 1595, 1604, 1619, 1625,1640 , and 1670 and even in the post-Karlowitz decree of $1700 .{ }^{26}$

\section{French Imperial Decrees}

The capitulations granted by the Mehmed the Conqueror were continued by Bayezid II. Some very intriguing lines appear in the text of the imperial decree that ratifies an agreement signed between the Mamelukes and France and was approved by Süleyman I. in 1528 after the Ottoman conquest of Egypt. For example, the manner in which the consul described how the French and Catalonians should act if they sustained damage carrying a load to the government or doing another job for it includes the following: "He shall convey the situation to the pertinent parties at the Sublime Porte with a few officials sent by the government. Once that is completed, he shall be escorted to the Consulate under the protection of the same officials. "27 Although these words imply distrust of the consuls, they also make clear that no Catalonians or French would be incarcerated for

\footnotetext{
${ }^{21}$ Kaçan 1995, p. 12.

${ }^{22}$ Aksin 2017, p. 72-82.

${ }^{23}$ Şakiroğlu 1983, p. 1567.

${ }^{24}$ Kaçan 1995, pp. 16, 51-55.

${ }^{25}$ Kaçan 1995, pp. 59-60.

${ }^{26}$ Kaçan 1995, pp. 67-68, 74-75, 78-79, 83-85, 91-99, 105-107, 113-114, 126-127, 142-145.

${ }^{27}$ Macar İskender and Ali Reşat 1330 [1914], p. 49.
} 


\section{Sedat BINGÖL - Hayrettin PINAR}

anything unrelated. ${ }^{28}$ It is interesting to see how the freedoms possessed by the consulates had expanded, as in this line: "As long as the consul bears this official title, his rights and powers cannot be limited. "29 While this is thought to refer to diplomatic immunity, it should be remarked that it marked a hasty anticipation, and more considered expressions describing consular immunity from incarceration were stipulated in imperial decrees dated 1535 and later.

Although there was a change in the existing immunity-related regulations occurred in 1535, it should not be overlooked that a new plateau in Ottoman diplomatic relations had clearly been reached with an improvement that was seen in the same year. The first French capitulations, bilaterally signed in 1535 , were remarkable and set a precedent for other states. In fact, in this agreement, a kind of state law process was initiated between Muslim and Christian states. ${ }^{30}$ The capitulations granted in the following years would proceed in relation to the personality of the legislation or on principles of extraterritoriality, according to which a citizen of a state brings the laws of that state along with them wherever they are. Thus, over time, a principle that had not had legal existence in the host country would become generally accepted. In other words, if foreign nationals of one power were before the law as a result of matters among themselves in the territory of another, they would be summoned to the consul or ambassador of the country of which they were citizens and under the legal framework of that country. On this principle, "the right of the King to judge his nationals in matters of law and punishment" devolved to his diplomatic representatives. Further, if a French national was led by debt to depart Ottoman territory, the French consul, his bailo, and other French nationals would not be subject to pressure or prosecution to pay that person's debt. ${ }^{31}$ However, this decree makes no direct mention of diplomatic immunity or any related matters.

The same matters were repeated in a decree of 1569 . However, it is noteworthy that the term consul, which appeared in the 1535 decree, was absent in the 1569 decree. $^{32}$ It was likely thought that all rights granted to an ordinary refugee would naturally be valid for the consul. The main point of innovation in this decree is the mild manner in which the French consuls were to be treated: "There will be no objection lodged regarding the replacement of French consuls in our country." From the point of view of diplomacy, there is no doubt that this new style was very important. Moreover, it should be noted that with this latter decree, the French had taken a few steps forward in regard to privileges, in that the rights previously granted only to the Venetians were now granted to the French. $^{33}$

In the renewal of capitulations granted to France in 1581, after a mention of Tripoli and Algeria, a remarkable difference appeared in the text: "In the case of a change in French consuls or MPs persons who shall be appointed and selected as their replacement

\footnotetext{
${ }^{28}$ Macar İskender and Ali Reşat, 1330 [1914], p. 50.

${ }^{29}$ Macar İskender and Ali Reşat 1330 [1914], p. 52.

${ }^{30}$ Yorulmaz 2000, pp. 698.

${ }^{31}$ Erim 1953, p. 10.

${ }^{32}$ Macar İskender and Ali Reşat, 1330 [1914], p. 76.

${ }^{33}$ Macar İskender and Ali Reşat, 1330 [1914], pp. 77-78.
} 


\section{Diplomatic Immunity and Encrypted Diplomatic Correspondence in the Ottoman Empire}

shall not be harassed and prevented from their tasks" ${ }^{34}$ While no process of granting an acceptance certificate was included in the treaty, in general, a charter would be provided that showed the consulate's rights and duties and indicated that the Porte had confirmed the appointment of the consul. In these charters, it was stated that, just as their personal property, servants, and animals would not be harmed in any way, inside or outside of the home, the consul's imports would also be exempt from customs tariffs. Envoys and consuls could also use whatever individuals they wished in their security detail and as their interpreters. ${ }^{35}$

In a 1597 treaty, it was recorded that the French ambassador, his consuls, and his translators were free to reside in and wander about Ottoman territory as they wished and to return to their country whenever they wished. It was added that French consuls could not be incarcerated, and their homes could not be seized. This, the freedom from arrest found in the French treaty with Egypt that was approved in 1528 by the Sultan Süleyman I was expanded again, 70 years later, to cover all Ottoman townships. Moreover, with the addition of the phrase "their residences could not be seized," another step was taken toward housing immunity. The 1597 decree registered in 1597 was followed by a revision dated 1604. This text gathered together elements mentioned in previous documents. Here, it is important to underline only the following items on diplomatic immunity.

- French consuls shall not be arrested and their homes shall not be seized.

- French consuls shall benefit from the permissions and exemptions granted to French envoys.

- Restitution for the debt or punishment for the misdemeanor of a French citizen fleeing from the Ottoman Empire can only be demanded from his official guarantor. the French. ${ }^{36}$

- All treaty permits and privileges granted to the Venetians shall also be applied to

Concessions reached the widest extent in a treaty dated 30 May, $1740:{ }^{37}$

"If some people complain about the consuls, they must not treat them as their enemy by imprisoning and sealing their homes... Issues stipulated in the treaty made with Venice are valid for the French as well, and the ambassadors and consuls of the King of France may employ the interpreters they want... They should not be reprimanded or imprisoned because of their duties." 38

\section{British Imperial Decrees}

The British had been visiting Ottoman ports from the 16th century onwards, and Sultan Süleyman I. granted the first trading permit to a British citizen to merchant Anthony Jenkinson in $1553 .{ }^{39}$ As commercial relations expanded, this initial permission

\footnotetext{
${ }^{34}$ Macar İskender and Ali Reşat, 1330 [1914], pp. 84-85.

${ }^{35}$ Kütükoğlu 1988, p. 538.

${ }^{36}$ Macar İskender and Ali Reşat 1330 [1914], pp. 86, 90, 93, 100-108.

37 Türk Tarih Kurumu vol.I 2008, pp. 4-14.

${ }^{38}$ Türk Tarih Kurumu vol.I 2008, pp. 17-20, 23-24.

${ }^{39}$ Kütükoğlu 2013, p. 13.
} 


\section{Sedat BINGÖL - Hayrettin PINAR}

was followed by an imperial decree issued in 1580. In this document, the British were granted permission to appoint consuls in Alexandria, Tripoli, Algeria, Tunisia, and other places. The replacement of these consuls would entail no consequences from the Ottomans. A framework close to contemporary diplomatic immunity can be seen in the following text: "If in fact the debtor is British, the debt should be taken from him. If he has no guarantor, another person should not be imprisoned." 40

Shortly after the decree of 1580, William Harborn was appointed the first British ambassador to the Ottoman capital. In addition to their responsibility in legal affairs, such as notarizing, birth and death recording, and protecting traders' rights, appointed consuls gradually began to have a say in political matters. ${ }^{41}$ As the British role in Ottoman lands expanded, a serious rivalry grew up between the European powers. It heated up even further with the distribution of most favored nation status. In 1601, the British were granted this privilege. ${ }^{42}$ In accordance with this, new provisions on immunity were added to the 1601 imperial decree, which stipulated that "Consuls representing Britain in Ottoman countries are under the auspices of the Empire. Under no circumstances will they be incarcerated, nor will their homes be sealed." 43

Capitulation rights, which were amended approximately 10 times, between added or removed text, were finalized in 1675 . In the 1675 decree, which remained valid until the signing of a free trade agreement with the British in 1838, important aspects of diplomatic immunity are enunciated: ${ }^{44}$

"Consuls will never be imprisoned and their residences will not be sealed. Consuls cannot be summoned and expelled... They can employ any escort guards they want... The British envoy is the deputy of the king of Britain, and the envoy's translators are also deputies... When they have committed crimes, judges cannot reprimand and harass individuals without informing their ambassadors or consulates. "45

France was clearly the forerunner here in diplomatic immunity. Ultimately, states that sought to obtain the benefits that accrued to France in 1740 obtained similar capitulations from the Sublime Porte. ${ }^{46}$

\section{Austrian Imperial Decrees}

Ottoman-Austrian political relations began with a legation sent by Emperor Ferdinand I in $1528 .{ }^{47}$ The treaty that resulted, signed in 1547 by Sultan Süleyman I. was the first written agreement with Austria. Nevertheless, no provision regarding immunity

\footnotetext{
${ }^{40}$ Dereli 1951, pp. 123-131.

${ }^{41}$ Kocabaşoğlu 2004, pp. 45-46.

42 Türkmen 1995, p. 333.

${ }^{43}$ Kütükoğlu 2013, p. 33. British diplomats were granted immunity for their envoys and residences in 1601, before the French were. Frey, and Frey 2020, 'Diplomatic Immunity', https://www.britannica.com/topic/diplomatic-immunity (accessed on February 23, 2020)

44 Arik 2016, p. 147.

45 Türk Tarih Kurumu vol.I 2008, pp. 245-246, 251, 258.

${ }^{46}$ Erim 1953, p. 6.

${ }^{47}$ Teply 1969, p. 248.
} 


\section{Diplomatic Immunity and Encrypted Diplomatic Correspondence in the Ottoman Empire}

was given in this text. ${ }^{48}$ The following lines in the relevant imperial decree of 1562 are quite remarkable: "Nobody can hinder the number of interpreters he uses. Nobody will interfere with officials coming and going to the government." ${ }^{49}$ Care was taken to put the agreement into writing as per established diplomatic practice. Moreover, the legal rights and security of tributary envoys and their staff (messengers and couriers) were also mentioned. The 1568 decree was important for its accommodating statements that left no doubt regarding diplomatic documents and messengers, such as "When the messenger has to come and go, he shall do so from the specified route. Nobody will hinder them and interfere with their documents and their person." ${ }^{50}$ This clearly provides for personal diplomatic and communications immunity. Nevertheless, it should be noted that these privileges were only considered valid during times of peace.

Indeed, just before the Thirteen Years' War, which began in 1593 and ended with the Treaty of Sitvatorok (1606), the Austrian envoy Herr von Kregwitz and his delegation were physically harassed. Von Kregwitz and his diplomatic committee were imprisoned for not adhering to Austria's pacta sunt servanda. Naturally, their diplomatic rights and the immunity of their documents were disregarded. The 1568 decree was renewed by Sultan Murad III in 1576. Although immunity is not mentioned encountered in the renewed imperial decree, it can understood from this statement: "The matters stipulated in the previously signed treaty will be valid as before," that the rights granted in 1568 were preserved in this revised decree. ${ }^{51}$

As noted, Ottoman-Austrian relations broke down in the latter part of the 16th century. Although the Treaty of Sitvatorok, which ended the extended conflict between the states, ushered in a change of Ottoman diplomacy, the same could not be said for immunity. However, the decree issued after the agreement with Austria is quite striking. Article 11 of the 1615 decree is especially interesting.

"Letters and messengers or viziers that are dispatched to my capital, as well as officials dispatched by gate chamberlains and governors to one other, are to be provided with a sufficient number of escorts at their sides in the provinces and shall transit safely with their permits. If the man of the envoys on that side and on our side is dispatched as messenger with a letter, the governor of Budapest shall pay close attention to this matter and have each delivered to the other without delay." 52

This text makes clear that the messenger and communications immunity were bilaterally guaranteed. Though the decree of 1615 was followed by that of 1628 and the Peace of Vasvar of $1664,{ }^{53}$ the latter two documents contain no such clauses. Finally, Articles 15 and 17 of the Treaty of Karlowitz, dated 1699, contains the following remarkable text.

"Article 15:

\footnotetext{
${ }^{48}$ Kurtaran 2006, p. 61.; Bozkurt 2002, p. 247.

${ }^{49}$ Kurtaran 2006, p. 66.

${ }^{50}$ Kurtaran 2006, p. 88.

${ }^{51}$ Kurtaran 2006, p. 97.

${ }^{52}$ Kurtaran 2006, pp. 169-170.

${ }^{53}$ Kurtaran 2006, pp. 175-182, 187-191
} 
Articles stipulated in the previous treaties, which are contrary to the conditions currently enforced and are not detrimental to the customs taxes of the two states are valid from this date forward, until determined null and void in one which is contrary.

\section{Article 17:}

And translators may be employed. Whenever their sons and other men go from Vienna to my capital and back again, they will be given road orders and assistance shall be provided whenever deemed necessary." 54

Compare also Article 18 of the 1718 Treaty of Passarowitz:

"Friends of the Ottoman Empire, the envoys and chargés d'affaires of the kings may employ translators, shall be provided messengers and officials from Austria to the Sublime Porte and vice-versa and assistance shall be given road orders as per the ancient laws and provided assistance whenever deemed necessary. "55

and Article 21 of the 1739 Treaty of Belgrade of, "whenever messengers and other men come and go from my capital to Vienna and vice-versa shall be given road orders and provided assistance whenever deemed necessary." 56 Thus, in the mid-18th century, the Ottoman State had also adopted diplomatic communications immunity for international relations.

\section{Messengers}

The Ottomans split the roads in Anatolia and Rumelia into three, the right, middle, and left branches. Accommodation stopovers were established along these roads, which they named menzil, ${ }^{57}$ to facilitate communications and ensure messenger safety. At all stopovers, the horses were fed, and official communications were conducted via the $u l a k,{ }^{58}$ who were regarded as military officials.

The menzils also facilitated the transport of envoys and statesmen to their posts. ${ }^{59}$ Those arriving from Istanbul were allocated horses by the stablemaster in charge of pack animals. Moreover, envoys were provided with fully armed soldiers as security. ${ }^{60}$ Generally called kavas (forbidden), these armed men were in the service of representatives and legations of foreign states, including envoys, consuls, and deputy consuls. $^{61}$

\footnotetext{
${ }^{54}$ Kurtaran 2006, 206-220; Bozkurt 1994, pp. 8-9.

${ }^{55}$ Kurtaran 2006, p. 271; Bozkurt 1994, p. 79.

${ }^{56}$ Kurtaran 2006, pp. 310-311.

57 The term menzil refers to the station where the horses are kept for the messengers. It was used mainly for official communication under the Ottomans. Halaçoğlu 2014, pp. 12-13

${ }^{58} \mathrm{An}$ ulak is a state-dispatched quick messenger who is sent from one place to another. See Sertoğlu 1986, p. 348; . Kepeci 1952, p. 377.

${ }^{59}$ Düzbakar 2007, pp. 182-194.

${ }^{60}$ Halaçoğlu 2014, pp. 53, 55-58.

${ }^{61}$ In Ottoman literatüre, Kavas referred to the Janissary messenger assigned with a seargent to protect envoys, consuls and their embassies. Canatar 2002, pp. 66-67.
} 


\section{Diplomatic Immunity and Encrypted Diplomatic Correspondence in the Ottoman Empire}

Diplomatic dispatch orders were requested for couriers following the aforementioned provisions of the Karlowitz, Passarowitz, and Belgrade Treaties. For instance, the following lines were written for a French courier on 21 May, 1736, during the reign of Mahmud I.

"To the French Ambassador to Istanbul Baron Roche from His Majesty, The Sultan,

This time, one of the French couriers named Buke has submitted a request to be provided with a road order in order to proceed to the border with a regiment of Tatar warriors from Istanbul past Belgrade.

Road order issued on 10 Muharrem 1149 [1733]" 62

Imperial edicts would be sent in this way to local authorities and port administrators to allow the messengers (later couriers) employed in the delivery of official correspondence to proceed safely in their communications tasks. Imperial decrees also assigned local mounted sentries to ensure the safe departure and return of their messengers:

"The law for the canonic judges, regents and officials and those who collect poll taxes are on the road from the Sublime Porte to the frontier is such; it is my edict to have Kaliboy Kaski, a Russian aristocrat who was appointed by the consulate and provided a charter, to travel to or from my capital from Russia whenever he desires with his entourage, personal effects and animals. He shall be received at messenger stations, at sea or on land to be escorted from township to township by trustworthy men while transiting dangerous districts.

Fî Evâil-i Muharrem 1201 [1785]" 63

Another, later, clause, dated June, 1792, reads "If Russian messengers arrive in any township, their safe passage shall be ensured throughout their arrival and departure through hazardous districts by means of salaried military personnel." 64

Another matter that often goes unnoticed in the dispatch orders given for the security details of other aliens in Ottoman dominions indicates the quality of the diplomatic couriers in these documents; this is touched upon in this sentence, "Protection on the road with the immediate posting of fully armed guards, which are required from the local Moslem community. " From this instance, recorded in 1785, it is evident that the state took care for the protection of its couriers. The Spanish envoy in Istanbul sent a local mounted sentry, an Albanian named Mehmet Beşe, to Spain, most likely as a courier. Mehmet Beşe was attacked on the Kaz Plain in Edirne province by a group of fifteen brigands, who seized his communiques, 300 piastres worth of personal effects, and 350 piastres in cash. The Spanish envoy applied to the Ottoman administration, requesting for the seized property to be restored and the criminals punished. An edict was sent to the commander of imperial guards at Edirne, calling upon him to pursue "The full and

\footnotetext{
${ }^{62}$ Its old name is the Prime Ministry Ottoman Archive (BOA). Its current name is Presidential Ottoman Archive (COA).(hereafter COA), AE/SMHD, no. I/64, 4159

${ }^{63}$ Maranc1 2017, pp. 151-152.

${ }^{64}$ Maranc1 2017, pp. 261-262.
} 


\section{Sedat BINGÖL - Hayrettin PINAR}

immediate capture... of the bandits who ransacked the goods, money, and documents of the armed guard dispatched by the envoy." 65

Beyond meeting the material loss as requested by the Spanish ambassador, the demand for the recovery of the official documents is also quite striking. Another important detail that must be mentioned concerns the terminology used. The term messenger was usually used in internal communications within the Ottoman Empire in the 18th and 19th centuries. The term courier, by contrast was used mostly to describe the diplomatic messengers of foreign states. However, once permanent ambassadorial offices were set up after $1795,{ }^{66}$ the word courier ${ }^{67}$ entered the vernacular and began to be used for Ottoman messengers dispatched to foreign nations.

\section{Conclusion}

Imperial decrees provided some degree of personal or residential immunity to diplomats or consuls assigned with credentials in Ottoman territories. Nevertheless, besides the rights granted to Austria, no definite provisions have been encountered as bestowed upon any state regarding diplomatic documents and communications immunity. Moreover, although the capitulations were abrogated with the Lausanne Treaty, diplomatic immunity was within the context of bilateral treaties and customary law. Because the 1961 Vienna Convention on Diplomatic Relations was only approved by Turkey in 1984 and implemented a year later, the tradition of recourse to customary law on this topic continued even after the foundation of the Republic of Turkey. In short, if the Austrian case is an exception, the absence of explicit statements on of diplomatic documents and communications immunity in relevant decrees indicates that questions of this type were to be assessed within customary law.

The clearly expressed stipulations on diplomatic documents and communications immunity in the Austrian case indicates that this matter was stated to define the relations between the states more precisely. However, one should avoid the misconception that one or another understanding was always valid. For example, the Austrians occupation of Transylvania in 1551 caused its representative in Istanbul, Malvezzi, from being imprisoned. ${ }^{68}$ As stated, Herr von Kregwitz and his diplomatic legation sought to intercede on behalf of Malvezzi just before the Ottoman-Austrian War, which began in 1593, but he was unable to prevent their incarceration.

Many examples like can be found throughout Ottoman history. Although these practices may appear to violate treaties and their clear provisions on immunity, they

\footnotetext{
${ }^{65}$ Demiryürek 2010, pp. 95-96.

${ }^{66}$ The first resident ambassador during the reign of Selim III (1789-1807) was Yusuf Agâh Efendi, who was appointed to London in 1793. Kuran 1988, pp. 11, 16

${ }^{67}$ Couriers are intermediaries who provide direct official communications between the government and envoys in foreign countries. Bilsel 1934, pp.173-174.; For a few examples of the use of the term courier see COA. A.DVN.DVE. no. 1-43; COA. DH.EUM.SSM. no. 1-51; COA. A.DVN.DVE no. 14-34; COA. C..HR.. no. 182-9063; COA. HAT no. 44-2213; COA. HAT no. 140-5808; COA. HAT no. 169-07179; COA. İ..MVL. no. 286-11331.

${ }^{68}$ Eyice 1992, pp. 466.
} 


\section{Empire}

undermine neither their spirit nor their matter because the provisions recorded were only valid during peace. In the event of a war, the representative and delegation of the relevant country could be imprisoned until the war ended. This tradition, which continued throughout the long centuries of the Ottoman Empire, was abandoned in the 19th century. For instance, during the Russo-Turkish War of 1806-1812, Ambassador Ditaninski was not imprisoned at Yedikule. Instead, he was summoned to the Sublime Porte, received warmly, and kindly requested to leave the country within 10 days. This indicates a desire on the part of the Ottoman authorities to adapt to standard European diplomatic practices while administering their own diplomacy. ${ }^{69}$

${ }^{69}$ Erdem 2008, pp. 375-376 


\title{
BIBLIOGRAPHY
}

\author{
a. Archival Documents State Archives of Turkey (COA) \\ COA. AE/SMHD, no. I/64, 4159 \\ COA. A.\}DVN.DVE. no. 1-43 \\ COA. DH.EUM.SSM. no. 1-51 \\ COA. A DVN DVE no. 14-34 \\ COA. C..HR.. no. 182-9063 \\ COA. HAT no. 44-2213 \\ COA. HAT no. $140 / 5808$ \\ COA. HAT no. 169-07179 \\ COA. I..MVL. no. 286-11331.
}

\section{b. Published Sources}

\begin{tabular}{|c|c|}
\hline Aksin 2017 & $\begin{array}{l}\text { Ahmet Aksın, "1482 Tarihli Osmanl1-Venedik Ahidnâmesi", N. } \\
\text { Alkan Günay(ed.), Sultan II. Bayezid Dönemi ve Bursa, } \\
\text { Osmangazi Belediyesi Yayynları, pp. } 72-88 \text {. }\end{array}$ \\
\hline Arık 2016 & $\begin{array}{l}\text { T. Arık, "Osmanl-İngiliz Ekonomik İliskilerinin Başlangıcının } \\
\text { Arka Plan1 ve } 1675 \text { Senesine Kadarki Seyri”, Marmara } \\
\text { Üniversitesi Öneri Dergisi, vol.12, no. } 45 \text {, pp. 137-152. }\end{array}$ \\
\hline Apaydin 2013 & $\begin{array}{l}\text { B. Apaydın, Kapitulasyonlar ve Osmanlı - Türk Adli ve İdari } \\
\text { Modernleşmesi, Adalet Yayınevi, Ankara }\end{array}$ \\
\hline Aybay 2009 & $\begin{array}{l}\text { R. Aybay, Tarih ve Hukuk Açısından Konsolosluk, İş Bankası } \\
\text { Yayınları, İstanbul }\end{array}$ \\
\hline Bilsel 1934 & $\begin{array}{l}\text { Cemil Bilsel, Devletler Arasinda Münasebat: Devlet Reisleri, } \\
\text { Hariciye Vekilleri, Konsoloslar, A. İhsan Matbaası, İstanbul }\end{array}$ \\
\hline Bozkurt 1994 & $\begin{array}{l}\text { N. Bozkurt, 1699-1736 Tarihli Ecnebi Defterine Göre XVIII. } \\
\text { Yüzyllın Illk Yarlsinda Osmanll-Avusturya Münasebetleri, } 19 \\
\text { May1s University, Master's Thesis }\end{array}$ \\
\hline Bozkurt 2002 & $\begin{array}{l}\text { Nurgül Bozkurt, "Avusturya Kapı Kethüdalı̆g } 1 \text { (1700-1736)", } \\
\text { OTAM vol.13, pp. } 245-259 .\end{array}$ \\
\hline Canatar 2002 & $\begin{array}{l}\text { M. Canatar, "Kavas", TDV İslâm Ansiklopedisi, vol.25, pp.66- } \\
68 .\end{array}$ \\
\hline Chardin 2014 & $\begin{array}{l}\text { J. Chardin, Chardin Seyahatnamesi, İstanbul, Osmanll } \\
\text { Topraklarl, Gürcistan, Ermenistan, Iran } 1671-1673, \quad \mathrm{~S} . \\
\text { Yerasimos (ed.), Kitap Yayınlar, İstanbul }\end{array}$ \\
\hline Coco 1991 & $\begin{array}{l}\text { C. Coco, “İstanbul'daki Venedik Topluluğu”, (trans.)M. H. } \\
\text { Şakiroğlu, Erdem, vol.7, no.20, pp. 667-687. }\end{array}$ \\
\hline Demiryürek 2010 & $\begin{array}{l}\text { M. Demiryürek, "Yabancı Konsolos, Konsolos Tercümanı ve } \\
\text { Tercüman Hizmetkârlarının Serbest Dolaşım Belgeleri: Beratlar } \\
\text { ve Yol Emirleri (1600-1800)", Kebikeç, no.30, pp. 89-104. }\end{array}$ \\
\hline
\end{tabular}




\section{Empire}

Dereli 1951

Deringil 1990

Düzbakar 2007

Erdem 2008

Erim 1953

Eyice 1992

Frazee 2004

Frey and Frey 2020

Gökbilgin 1952

Gürkan 2014

Gürkan 2017

Halaçoğlu 2014

İnalc1k 2000

Kaçan 1995

Karakoç 2004

Kepeci 1952, Kocabaşoğlu 2004
H. Dereli, Kraliçe Elizabeth Devrinde Türkler ve Ingilizler, Ankara Üniversitesi Yayınları, İstanbul

S. Deringil, "II. Mahmud'un Dış Siyaseti ve Osmanlı Mirası", Sultan II. Mahmud ve Reformları Semineri, Istanbul Universitesi Yay., pp. 59-70.

Ö. Düzbakar, “XV-XVIII. Yüzyıllarda Osmanlı Devleti'nde Elçilik Geleneği ve Elçi İaşelerinin Karşılanmasında Bursa'nın Yeri”, Uluslararası Sosyal Araştırmalar Dergisi, vol.2, no.6 , pp. 182-194.

G. Erdem, Osmanlı İmparatorluğu'nda Sürekli Diplomasi'ye Geçiş Süreci, Ankara University, Ph.D. Dissertation N. Erim, Devletlerarası Hukuku ve Siyasi Tarih Metinleri, TTK Yayınları, Ankara

S. Eyice, "Busbeke, O. Giselijn Van (1522-1592)", TDV İslâm Ansiklopedisi, vol. 6

C. A. Frazee, "İstanbul'un Fethinden Sonra Osmanlıların Kazanımları ve Katoliklerin Tepkisi”, (trans.) M. Şahin, Selçuk Üniv. Illahiyat Fakültesi Dergisi, vol. 17, No.17, pp. 211-236.

L. Frey, and Marsha L. Frey, "Diplomatic Immunity", https://www.britannica.com/topic/diplomatic-immunity

Accessed on February 23, 2020.

T. Gökbilgin, "Konsolos", MEB İslâm Ansiklopedisi, vol. 6, pp.836-840.

E. S. Gürkan, "50 Günde Devr-i Bahr-i Sefid: Königsbergli Lubenau'nun Kadırgayla İmtihanı", Osmanlı Araştırmalar Dergisi, vol.43, no.43, pp. 273-300.

E. S. Gürkan, Sultanın Casusları, Kronik Yayınları, İstanbul

Y. Halaçoğlu, Osmanlılarda Ulaşım ve Haberleşme (Menziller) İlgi Kültür Sanat Yayınları, İstanbul

H. İnalcık, "İmtiyazat”, TDV İslâm Ansiklopedisi. vol.22, pp. 245-252.

M. Kaçan, XVI. ve XVII.Yüzyıllarda Osmanl-Venedik Ahidnâmeleri, Marmara University, Master's Thesis,

İ. Karakoç, “Türk Hukuk Tarihi’nde Uluslararası Antlaşmaların Uluslararası Hukukun Gelişim Sürecindeki Yeri”, Dokuz Eylül Üniversitesi Hukuk Fakültesi Dergisi, vol.6, no.2, pp. 199-253.

K. Kepeci, Tarih Lugatı, Tan Matbaası, İstanbul

U. Kocabaşoğlu, Majestelerinin Konsoloslarl (İngiliz Belgeleriyle Osmanlı Imparatorluğu'ndaki İngiliz Konsoloslart (1580-1900), İletişim Yayınları, İstanbul 
Kuran 1988

Kurtaran 2006

Kütükoğlu 1988

Kütükoğlu 2013

Macar İskender and Ali Reşat 1330 [1914]

Macar İskender and Ali Reşat, Kapitülasyonlar, Kanaat Matbaas1, Dersaadet

Maranc1 2017

Mattingly 1955

Mumcu 2014,

Pamir 2002

A. Maranc1, "86/4 Numaralı Rusya Ahkâm Defterinin Transkripsiyon ve İncelenmesi (Issues 1-95)", Kırklareli University, Master's Thesis,

G. Mattingly, Renaissance Diplomacy, Houghton Mifflın Company, Boston

Serap Mumcu, Venedik Baylosu'nun Defterleri (1589-1684), Edizioni Ca' Foscari, Venezia

A. Pamir, "Kapitülasyon Kavramı ve Osmanlı Devleti'ne Etkileri”, Ankara Üniversitesi Hukuk Fakültesi Dergisi, vol.51, no.2, pp. 79-119.

Pilat and Criesta 2018 L. Pilat and O. Criesta, The Ottoman Threat and Crusading on the Eastern Border of Christendom during the $15^{\text {th }}$ Century, Brill, Leiden

Potyemkin 2009

Sertoğlu 1986

Şakiroğlu 1983

Türk Tarih Kurumu 2008 Vladimir Potyemkin (ed.), Uluslararası İlişkiler Tarihi 1: Diplomasi Tarihi, (trans.) A.Tokatl1, Evrensel Basım-Yayın, vol. 1, İstanbul

M. Sertoğlu, Tarih Deyimleri Sözlüğü, Enderun Kitapevi, İstanbul

M. Şakiroğlu, "1503 Tarihli Türk-Venedik Antlaşması", VIII. Türk Tarih Kongresi, vol. III, pp. 1559-1569.

Türk Tarih Kurumu, Muâhedât Mecmûast, vol. I, TTK Yayınları, Ankara

Teply 1969

Turan 1990,
Karl Teply, "Nemçe Imparatorlarının İstanbul'a Yolladığı Elçi Heyetleri ve Bunların Kültür Tarihi Bakımından Önemli Tarafları", (trans.) B. S. Baykal, DTCF Tarih Araştırmalarl Dergisi, no.12, pp. 247-263.

İstanbul
Ş. Turan, Türkiye-İtalya İlişkileri I, Metis Yayınları, 
Diplomatic Immunity and Encrypted Diplomatic Correspondence in the Ottoman Empire

Türkmen 1995, Z. Türkmen, “Osmanlı Devleti'nde Kapitülasyonların Uygulanışına Toplu Bir Bakış”, OTAM, vol.6, p. 325-341.

Uzunçarşılı 1988, İ. H. Uzunçarşılı, Osmanlı Tarihi, Vol. III-II, TTK Yayınları, Ankara

Wratislaw 1996, W. Wratislaw, Baron W. Wratislaw'ın Anılarl, (trans.) M. Süreyya Dilmen, Boyut Yayınları, İstanbul

Yorulmaz 2000, S S S. Yorulmaz, “Osmanlı-Fransız İlişkileri Çerçevesinde Osmanlı Topraklarında Açılan Fransız Kültür Kurumları ve Bunların Meşruiyet Kazanması 19.Yüzyıl-20.Yüzyıl Başları”, OTAM, vol.11, pp. 697-768. 